\title{
Research of the method for graduation practice based on campus practice teaching
}

\author{
Yuqin Yao ${ }^{1, a}$, Kechang $\mathrm{Fu}^{1}$, Hanbing Yan ${ }^{1}$, Xiaoyan Huang ${ }^{1}$, Dan \\ Chen ${ }^{1}$,Guojiang Wang ${ }^{1}$,Wenbin Wang ${ }^{2}$ \\ ${ }^{1}$ Chengdu University of Information Technology, Chengdu, 610225, China \\ ${ }^{2}$ Yalong River Hydropower Development Company LTD, Chengdu, 610051, China \\ ${ }^{a}$ Email: yyq@cuit.edu.cn
}

Keywords: graduation practice; practice teaching; school-enterprise cooperation; CDIO; reform

\begin{abstract}
Graduation practice is an important part of the teaching process, and it has great significance to cultivate high-quality, strong ability, meet the social market demand compound talents. This paper describes the construction of campus practice teaching base, school-enterprise cooperation in personnel training system and evaluation system of practice teaching base. The practice teaching model of school-enterprise cooperation builds employment platform between businesses and students. Improve the quantity and quality of personnel training campus practice teaching base, providing an important guarantee for the implementation of CDIO practice teaching and excellent engineer training program. Practice teaching of school enterprise cooperation, should be involved in the coordination of united government, guidance and management of school and enterprise, take the student as the main body, to cultivate the students' comprehensive practical ability and occupation accomplishment, conveying high skilled, high-quality talents for the society.
\end{abstract}

\section{Introduction}

The graduation practice is to develop students' practical ability, analytical and problem-solving skills, the ability using basic knowledge and skills enhance the students' 'ability to adapt social and employment competitive ness ${ }^{[1]}$. So the graduation practice is an important part in teaching plan and training programs, it is also an important way to combine classroom teaching and social practice. What's more, it is an indispensable bridge for student between the school and the community.

\section{Status of College Students practice teaching}

Over the past 20 years, in order to deal with the short age and quality of engineering education engineering talent which can not meet the needs of industry issues, many countries set off a wave of engineering education reform and have far-reaching reforms ${ }^{[2]}$. For example, the US National Research Council, National Academy of Engineering and the American Society of Engineering Education have launched investigations and develop strategic plans to vigorously promote the reform of engineering education.

China has become a truly engineering education country, but the trained engineering students practical ability is weak, poor sense is innovation, there is a wide gap between engineering innovation. How to encourage Chinese engineers "excellent" have become a problem and the whole community education project of common concern. In this context, the Ministry of Education launched the "excellent engineer education and training program." on June 23, 2010. In fact, the "Excellence" will be the main unit for a college co-cultured without standing engineers, calling for "Excellence" participating universities and enterprises in the culture of excellence throughout the process engineer to conduct a comprehensive, systematic and close cooperation, and practice teaching base the building is generally in the form of school-enterprise cooperation in personnel training. 


\section{Problems practice teaching school-enterprise cooperation}

The school practice teaching base is the extend of school Practice teaching, to improve the school practice teaching base, establishing a sound base for graduation practice on school-enterprise cooperation. The school practice teaching base should rely on practice bases for the purpose of teaching, teaching content, teaching standards, teaching methods and teaching building management and scientific innovation.

Campus practice teaching base construction, operation and evaluation are the key to excellence in engineering education and training of engineers ${ }^{[3]}$. But the universities in the establishment of practice teaching base and enterprises, also faces many difficulties. Firstly, lacking the effective school-enterprise cooperation mechanism makes school-enterprise cooperation lower lever, and the school teaching practice bases in a hot situation. Secondly, the scientific and rational teaching training mechanism is inadequate. What's more, doesn't fully play the role of a bridge for students and employment. Finally, it doesn't have scientific and reasonable method for quantitative evaluation for the campus practice educational base.

\section{1) Lack of effective cooperation mechanism.}

Most colleges and universities lack of the dynamic mechanism of common development, drive mechanism based on mutual benefit win-win in the process of school-enterprise cooperation ${ }^{[4]}$. It is difficult to carry out the two sides of school-enterprise multi-level communication and develop the school-enterprise cooperation depth and breadth.

\section{2) The Lack of engineering personnel training cooperation program}

Due to the lack of school-enterprise cooperation system overall planning, the lack of comprehensive consideration to the interests of both parties, school-enterprise cooperation in engineering education plans are not educating people, a lot of work is only temporary, periodically make arrangements, which need to be implemented only in order training, build bases, internships and other matters, the relevant personal shall be determined by the contact us. Thus, school-enterprise cooperation between the two sides often spend a lot of time and effort, but the benefits are not apparent cooperation, and cooperation in personnel training in full compliance with the requirements of the business needs which is a big gap.

3) Did not give full play to the role of a bridge in business practice teaching base of recruitment and student employment

In fact, based on the depth of cooperation between college and enterprises, the students fully understand the characteristics and capabilities can be participating in all aspects of the practice. Students also have in-depth study of the corporate culture, management and technology, so the two sides have combined with a high degree ${ }^{[5]}$.

4) The lack of proper training quality evaluation

The engineering talent training mechanism still does not get rid of the heavy theory, light practice effect evaluation system and ideas, and lack of reasonable quantitative evaluation for off-campus practice teaching base construction.

\section{Practice Educational Reform and Research}

The practice educational base mode refers to schools and businesses to build graduation practice, combined with engineering excellence in education and training of engineer program philosophy, the student's graduation practice, graduation design bases on practice, make full use of corporate resources to achieve the depth of cooperation between schools and enterprises, so that the school and the companies jointly cultivate high-quality, high-skilled personnel.

\section{1) Safeguard Mechanism}

The main jobs of the engineering students are production, technical and management positions. The practice is important part of achieving training objectives, quality practice. Practice base includes campus and off-campus practice base. Because lacking of investment funds, training equipment is inadequate and outdated, and a general lack of engineering faculty of engineering 
practice experience is difficult to satisfy any outstanding engineer training. These deficiencies can only be made up and strengthen by working with businesses. The campus practice teaching based on an important form of school-enterprise cooperation. The school-enterprise cooperation internship base model requires local businesses and schools to construct actively, requires improving the irenthusiasm, initiative and creativity. As a local government departments, should be actively involved in the school enterprise cooperation. Encourage enterprises to accept the school enterprise cooperation in policy, such as the relief enterprise tax, participating in the auxiliary support, participation in project priority policies and measures. Colleges, enterprises, businesses and governments and other parties involved in the subject, and the benefits and win-win is the realization of the inherent power of this process. There fore, in the process of the cultivation of engineering talent, only clearly different participation main body role orientation and motive of cooperation, can we achieve the win-win interests of different subjects, to enhance the efficiency of school enterprise cooperation personnel training.

\section{2) training mechanism}

Outside school practice base has the advantage of a complete production line for manufacturing enterprises and more advanced technology and equipment, can provide real and vivid practice environment for students. The formalism of most of the off campus practice base, practice content empty. The effect is not ideal. In order to make good use of the resources of practice base, the operation mode of practice teaching for scientific and rational planning is very necessary. Outside school practice teaching should combine students' training plan and schedule, the actual situation of the enterprise is important, according to the enterprise the production rhythm, reasonable arrangement of time. In order to enhance students' comprehensive ability for off-campus practice teaching content arrangement, it is necessary to combine professional development programs and training objectives. Consider the theoretical and practical aspects of the order and the cognitive processes of students staged continuity, and follow the discipline of knowledge and professional characteristics of the course, focusing on the intrinsic link between the various sectors. This practice can achieve the purpose of teaching school and provide talent demand for business. Develop learning tasks and content by schools, colleges, enterprises guidance and management, it achieved good results.

\section{3) Evaluation method}

It doesn't establish a scientific, standardized assessment method of teaching and assessment practice standard. Many scholars have made efforts in many ways for campus practice teaching bases, and made a number of practical teaching base assessment program. But the practice teaching base relevant to the assessment of theoretical research and practical method. It is still far behind the requirements which are mainly restricted to research too much emphasis on the importance of building a base for teaching practice and how construction and other aspects, the lack of college practice teaching base, especially Research practice Educational Base evaluation system. Graduation Practice examination is to test the quality of students graduating from the main part of the intern ship. For graduation practice, school and enterprise to tracking management, instructor at any time at the scene to guide and supervise the students training, record the ordinary performance, fill internship report. The combination of students' internship diary, internship report and results of graduation design and graduation reply the comprehensive evaluation. College student internships based on the results of a comprehensive assessment of business school and the selection of outstanding team, outstanding graduate design and instructor, a scientific evaluation system. Completed late practice, schools and businesses can maintain long-term contact to track achievements and research the strengths and weaknesses of continuous internship base model.

\section{Conclusions}

Campus practice teaching base construction, operation and evaluation are keys for excellence engineering education and training of engineers. Practice teaching model of school-enterprise cooperation between businesses and students build up employment platform. Making full use of corporate resources to achieve the depth of cooperation between schools and enterprises, so that the 
school and the companies jointly cultivate high-quality, high-skilled personnel. Article from the interests of the school and the joint venture, the introduction of new methods of systems engineering analysis makes the evaluation index more scientific, more reasonable.

\section{References}

[1] Mengmei. "Management of Graduation Project or Thesis in the University", Journal of Wuhan University of Technology, 2007, Vol 29 No. 1, pp: 3-86

[2] Xiaolin Li, Yanduo Zhang. The Reform of Computer Course System for Non-Computer Professional [J]. China Adult Education, 2008(2): 149-150.

[3] Yaping Wang. Exploration on the Teaching of Computer Base in Universities [J]. China Education Informationization, 2011(15):78-80.

[4] Wenbin Cheng. Discussion on the Teaching Reform of Computer Base for Non-computer Professionals [J]. China Power Education, 2011(4):66-67.

[5] Innovation and Construction of the Training Patterns of Engineering Talents Composites[A]. Proceedings of Conference on Creative Education (CCE2012) [C]. 2012 